Jurnal IImiah AL-Jauhari (JIAJ)

Volume 2 No 2, Desember 2017

ISSN: 2541-3430

E-ISSN: 2541-3449

Halaman 178-192

\title{
Kompetensi Supervisor terhadap Peningkatan Budaya Kerja Guru
}

\author{
Oleh: \\ Haira Molotolo
}

\begin{abstract}
ABSTRAK
Kompetensi supervisor dalam pengawasan budaya kerja guru di MA Anggrek dapat dibuktikan oleh adanya kemampuan kepala madrasah dalam merencanakan dan melaksanakan serta mengevaluasi pelaksanaan supervisi yang dilakukan dengan mengedepankan nilai-nilai humanisme dalam kaitanya dengan peningkatan budaya kerja guru MA Anggrek sehingga guru tidak saja profesional dalam melaksanakan tugas dan tanggungjawabnya tetapi juga memiliki kompetensi sosial dan kepribadian yang sesuai dengan diharapkan. Faktor-faktor yang mempengaruhi peningkatan budaya kerja guru terdiri atas: Faktor pendidikan merupakan syarat yang penting untuk memegang jabatan tertentu, komitmen kepala madrasah dalam melakukan tugas dan fungsi sebagai supervisor, komunikasi yang terjalin antara kepala madrasah dengan guru yang baik, dan motivasi yang tinggi dari guru dan kepala madrasah dalam pelaksanaan supervise di MA Anggrek. Efektifitas tugas dan fungsi Kepala Madrasah terhadap budaya kerja guru di Madrasah Aliyah Anggrek telah dirasakan oleh guru melalui peningkatan budaya kerjanya sehingga terjadi perubahan pada kemampuannya merencanakan kegiatan pembelajaran; melaksanakan kegiatan pembelajaran; menilai proses dan hasil pembelajaran; memanfaatkan hasil penilaian bagi peningkatan layanan pembelajaran; memberikan umpan balik secara tepat, teratur, dan terus menerus kepada peserta didik, perubahan dalam perilaku melayani peserta didik yang mengalami kesulitan belajar; menciptakan lingkungan belajar yang menyenangkan; mengembangkan dan memanfaatkan alat bantu dan media pembelajaran; memanfaatkan sumber belajar; mengembangkan interaksi pembelajaran yang tepat, dan budaya kerja guru.
\end{abstract}

Kata Kunci: Kompotensi, Supervisor, Budaya Kerja.

\section{Pendahuluan}

Pendidikan merupakan suatu usaha dan kegiatan sadar yang dengan sengaja direncanakan untuk mencapai tujuan yang telah ditetapkan. Pendidikan bertujuan untuk meningkatkan kualitas sumber daya manusia. Upaya peningkatan 
Sumber Daya Manusia yang berkualitas hanya dapat dicapai melalui pendidikan, baik formal maupun non formal. Itulah sebabnya, pendidikan tetap menjadi tema sentral bagi kegiatan-kegiatan yang berkaitan dengan SDM, dan pendidikan selalu berusaha dan harus mendapat tempat penting serta fokus perhatian yang lebih intens dan penuh keseriusan guna peningkatan mutu pendidikan agar tercapai Sumber Daya Manusia yang sesuai dengan tuntutan global.

Peningkatan kualitas Sumber Daya Manusia tak terkecuali kepala madrasah sebagai pengawas mutlak dilaksanakan, karena persoalan yang mendasar sesungguhnya terletak pada abstraksi atau daya nalar dan komitmen kepala madrasah dalam melaksanakan tugasnya, yang masih perlu dipertanyakan. Rendahnya kualitas guru termasuk budaya kerjanya saat ini, disebabkan karena kompetensi kepala madrasah sebagai supervisor belum dilaksanakan dengan baik. Kepala madrasah hendaknya memperhatikan kompetensi yang harus dikuasai.

Kegiatan supervisi merupakan bentuk layanan yang diberikan pada guru agar memiliki kecakapan dan kemampuan dalam pembelajaran. Dalam konteks ini supervisi merupakan pelayanan disediakan oleh kepala madrasah untuk membantu guru, agar menjadi guru yang profesional sesuai dengan perkembangan ilmu pengetahuan pada umumnya dan ilmu pendidikan pada khususnya. ${ }^{1}$

Undang-Undang Nomor 20 Tahun 2003 tentang Sistem Pendidikan Nasional bahwa tugas kepala madrasah sebagai supervisor yang diharapkan dapat setiap kali berkunjung ke kelas dan mengamati kegiatan guru yang mengajar. Mengingat di bidang pendidikan diperlukan penyelia (supervisor) yang dapat berdialog serta membantu pertumbuhan pribadi guru sesuai dengan profesinya. ${ }^{2}$

Kepala madrasah sebagai pimpinan pendidikan di madrasah, mempunyai peranan dalam melaksanakan supervisi karena bertanggungjawab terkait dengan pengembangan profesi guru terfokus pada ketiga aspek kemampuan guru yakni: kemampuan merencanakan pembelajaran; melaksanakan pembelajaran, dan mengevaluasi pembelajaran agar berlangsung seoptimal mungkin. ${ }^{3}$

Sebagai tolok ukur keberhasilan kepala madrasah dalam pelaksanaan supervisi adalah sampai sejauhmana perubahan telah dicapai, akibat pengaruh pelaksanaan supervisi terhadap kinerja guru. Keberhasilan ini tentu didukung oleh pengetahuan dan keterampilan yang dimiliki kepala madrasah terhadap fungsi, prinsip dan penerapan teknis supervisi itu sendiri.

Sebagai supervisor kepala madrasah belum memiliki kompetensi menjawab masalah antara lain: kepala madrasah merasa supervisi adalah tugas pengawas; kegiatan supervisi menekankan aspek administrasi dan mengabaikan proses pembelajaran; supervisor enggan melaksanakan supervisi karena perbedaan hierarki jenjang pendidikan; jabatan rangkap dari kepala madrasah, yakni sebagai

\footnotetext{
${ }^{1}$ Piet A.Sahertian, Konsep Dasar dan Teknik Supervisi Pendidikan Dalam Rangka Pengembangan SDM, (Jakarta, Bumi Aksara, 2000), h.16.

${ }^{2}$ Departemen Pendidikan Nasional RI, Undang-undang Republik Indonesia Nomor 20 Tahun 2003 Tentang Sistem Pendidikan Nasional, (Bandung: Citra Umbara; 2003), h. 23.

${ }^{3}$ Wina Sanjaya, Strategi Pembelajaran, (Jakarta: Prenada Media Group, 2008), h. 45.
} 
administrator sekaligus pimpinan madrasah sehingga supervisi sering terabaikan, karena kesibukan; minim pengetahuan supervisor terkait tugasnya. ${ }^{4}$

Untuk itu kepala madrasah sebagai supervisor, dituntut selalu bersifat profesional melalui kompetensi yang dimilikinya sebab tanpa kompetensi dan profesionalisme tinggi, tugas pembinaan dan pengawasan yang dilaksanakan bisa gagal atau tidak berhasil sesuai dengan yang diharapkan. Hal ini mengindikasikan betapa strategisnya posisi supervisor, di mana kepala madrasah sebagai seorang supervisor perlu meningkatkan kompetensinya melakukan pengawasan khususnya berkaitan dengan budaya kerja guru.

Jika mengacu kepada Peraturan Mendikbud Nomor 66 Tahun 2013 dinyatakan bahwa pelaksanaan dan pelaporan penilaian pendidikan terdiri atas: pelaksanaan dan pelaporan penilaian hasil belajar oleh pendidik; pelaksanaan dan pelaporan penilaian hasil belajar oleh satuan pendidikan; dan pelaksanaan dan pelaporan penilaian hasil belajar oleh Pemerintah. ${ }^{5}$

Tampaknya salah satu yang perlu dilakukan oleh guru yaitu hendaknya dapat menerapkan budaya kerja dalam proses pembelajaran. Agar budaya kerja ini dapat terwujud dalam aktivitas pembelajaran, maka siswa akan menjadi aktif dalam belajarnya. Siswa ditempatkan sebagai subjek belajar yang memegang peranan utama untuk mencari kemampuan apa yang dibutuhkan dirinya. Di sini guru berfungsi sebagai fasilitator dan motivator dengan budaya kerja yang tinggi. Artinya guru memberikan dorongan agar siswa mempunyai semangat belajar, jangan sampai siswa lebih banyak menerima apa yang disampaikan oleh gurunya saja.

Kroeber \& Kluckhohn dalam Rahman menyebutkan bahwa kebudayaan berasal dari bahasa sansekerta buddayyah, yaitu bentuk jamak dari buddhi yang berarti akal. Dengan demikian ke-budaya-an dapat diartikan hal-hal yang berhubungan dengan akal. Kebudayaan sebagai pola iksplisit dan implisit perilaku yang dipelajari dan diwariskan melalui simbol-simbol yang merupakan prestasi khas manusia, dan termasuk perwujudannya dalam benda-benda budaya. ${ }^{6}$

Pengertian lain, yaitu kebudayaan sebagai salah satu sumber utama sistem atau tata nilai suatu masyarakat. Sistem ini yang dihayati oleh seorang atau yang berlaku dalam suatu masyarakat bukan saja mencerminkan kebudayaan, tetapi sekaligus menentukan dan membentuk sikap mental yang terpantul dalam pola tingkahnya sehari-hari dalam berbagai segi kehidupannya. Jadi budaya kerja di sini adalah perwujudan kekuatan akal pikiran atau kemampuan intelektual dan sifat non intelektual, serta nilai-nilai yang direfleksikan dalam keseluruhan tata cara atau tindakan guru dalam suatu pekerjaan untuk memperoleh dan mengkonstruksi ilmu pengetahuan.

Budaya kerja dituntut untuk ditampilkan dari seorang guru dalam pembelajaran sehingga dapat meningkatkan kualitas pembelajaran. Untuk dapat merealisasikan hal ini, guru hendaknya berupaya untuk memilih dan

\footnotetext{
${ }^{4}$ Made Pidarta, Pemikiran Tentang Supervisi Pendidikan (Jakarta: Bumi Aksara, 2002), h. 26.

${ }^{5}$ Permendikbud Nomor 66 Tahun 2013 Tentang Standar Penilaian

${ }^{6}$ John Rahman, Budaya Kerja Guru dalam Meningkatkan Kualitas Pembelajaran di Sekolah (Jurnal Pendidikan Normalita) (Gorontalo: Program Pascasarjana, UNG, 2005), h. 121.
} 
melaksanakan berbagai pendekatan dan model pembelajaran yang sistematis dan tepat guna dengan tetap konsisten dengan budaya kerja.

Selain itu, bagi guru yang profesional harus berupaya secara sadar dan terencana dalam menyiapkan peserta didik untuk mengenal, memahami, menghayati hingga mengimani, bertaqwa, dan berakhlak mulia dalam mengamalkan ajaran agama Islam dari sumber utamanya kitab suci Alquran dan Hadis. $^{7}$

Adapun ayat yang bisa dijadikan sebagai landasan hukum tentang adanya kewajiban di atas yaitu firman Allah:

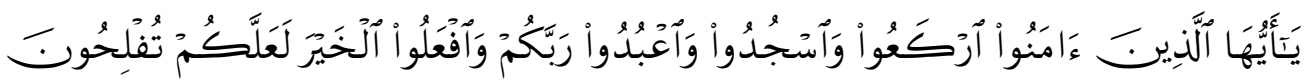

Terjemahnya:

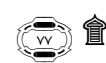

Hai orang-orang yang beriman ruku'lah kamu, sujudlah kamu sembahlah Tuhanmu dan berbuatlah kebajikan (prestasi) supaya kamu mendapat kemenangan. (Q.S. al-Hajj:77) ${ }^{8}$

Selain proses pembelajaran harus dikelola dengan baik, guru seharusnya menciptakan suasana kelas yang menyenangkan, rileks dan tidak tegang yang dapat dijadikan sebagai budaya kerja. Di dalam kelas terjadi komunikasi multi arah yang harmonis. Dengan budaya kerja semacam ini biasanya siswa akan merasakan suasana yang lebih menyenangkan sehingga kualitas pembelajaran dapat dimaksimalkan. Dengan budaya kerja yang demikian, pada akhirnya akan mengacu pada tercapainya tujuan pendidikan Nasional.

Berdasarkan observasi awal yang penulis lakukan menunjukkan bahwa semestinya tidak ada toleransi mengenai keterlambatan jam masuk kerja namun tampaknya di Madrasah Aliyah Anggrek saat ini ada toleransi 5 menit. Jam masuk kerja pukul 07.15 , terlambat hingga pkl. 07.20 masih belum dianggap terlambat, mengingat terlambat masuk kerja adalah soal mindset, seperti halnya budaya jam karet yang lebih banyak terkait dengan mindset.

Keterlambatan masuk kerja bukanlah soal sepele. Hal ini sebenarnya bisa menjadi cerminan diri bagi guru yang kesulitan melakukan manajemen diri. Jika keterlambatan masuk kerja soal sepele, tapi dalam kenyataannya guru di Madrasah Aliyah Anggrek tampaknya belum secara keseluruhan mampu menerapkannya dalam pekerjaan yang terkait dengan penerapan budaya kerja di lingkungan kerjanya.

Bertitik tolak dari kegelisahan akademik di atas maka penulis terdorong melakukan suatu penelitian yang berjudul: Kompetensi Supervisor terhadap Pengawasan Budaya Kerja Guru (Studi Atas Fungsi Kepala Madrasah sebagai Supervisor di Madrasah Aliyah Anggrek Kecamatan Monano Kabupaten Gorontalo Utara).

\footnotetext{
2003). h. 1.

${ }^{7}$ Dasim Budimansyah, Model Pembelajaran Berbasis Portofolio (Bandung: Genesindo, ${ }^{8}$ Departemen Agama, Alquran dan Terjemahnya (Bandung: Diponegoro, 2004), h. 22.
} 


\section{a. Kompetensi Supervisor dalam Pengawasan Budaya Kerja Guru}

Terdapat beberapa tugas/fungsi dan tanggung jawab kepala madrasah sebagai supervisor pembelajaran di MA Anggrek. Secara umum, kegiatan atau usaha-usaha yang dilakukan oleh kepala madrasah sesuai fungsinya sebagai supervisor ialah mencakup kegiatan atau usaha sebagai berikut: (1) Membangkitkan dan merangsang guru-guru dan pegawai madrasah dalam melaksanakan tugasnya masing-masing dengan sebaik-baiknya, (2) berusaha mengadakan dan melengkapi alat-alat perlengkapan madrasah termasuk media instruksional yang diperlukan bagi kelancaran keberhasilan pembelajaran, (3) bersama guru-guru berusaha mengembangkan, menggunakan, dan mencari metode mengajar yang lebih sesuai dengan tuntutan kurikulum baru, (4) membina kerjasama yang baik dan harmonis di antara guru-guru dan pegawai madrasah lainnya, (5) berusaha mempertinggi mutu dan pengetahuan guru-guru dan pegawai madrasah, antara lain dengan mengadakan diskusi kelompok, menyediakan perpustakaan madrasah, dan/atau mengirim para guru dan pegawai untuk mengikuti penataran, seminar, dan kegiatan ilmiah lainnya sesuai bidangnya masing-masing, dan (6) membina hubungan kerjasama yang baik antara madrasah dengan komite madrasah, orang tua peserta didik, masyarakat, dan instansi lain yang terkait dalam rangka peningkatan mutu pendidikan di madrasah. ${ }^{9}$

Kepala madrasah mengemukakan bahwa tugas dan tanggung jawab kepala madrasah dalam supervisi di madrasah, yaitu: Melakukan perencanaan kegiatan yang akan dilakukan di madrasah bersama staf guru dan staf madrasah lainnya, melakukan pengorganisasian kegiatan di madrasah, melakukan kegiatan penggerakkan kepada semua staf di madrasah, melakukan kegiatan supervisi terhadap aktivitas-aktivitas yang dilakukan oleh para staf guru dan staf madrasah lainnya di madrasah, dan menilai proses kerja dan hasil kerja yang dicapai oleh para staf dalam melakukan kegiatannya masing-masing di madrasah. ${ }^{10}$

Melalui kemampuan kepala madrasah melaksanakan supervisi tampaknya telah mampu mengidentifikasi para guru yang bermasalah atau yang kurang profesional dalam melaksanakan tugas, sehingga pada akhirnya diketahui titik kelemahan yang menghambat pencapaian tujuan pendidikan untuk selanjutnya segera dicarikan solusinya.

Dari sajian data di atas dapat disimpulkan sebagai berikut :

1) Tugas dan tanggungjawab supervisor, memiliki beberapa peranan yang harus dilaksanakan oleh kepala madrasah. yaitu mengenal masalah pembelajaran, berperan sebagai nara sumber, sebagai komunikator antar pribadi, dan sebagai agen pembaharuan dalam sistem madrasah.

2) Peran kepala madrasah sedemikian penting untuk menjadikan sebuah madrasah pada tingkatan yang efektif. Asumsinya adalah bahwa madrasah yang baik akan selalu memiliki kepala madrasah yang baik, artinya kemampuan profesional kepala madrasah dan kemauannya

\footnotetext{
${ }^{9}$ Dokumen Program Kerja Kepala Madrasah Aliyah Anggrek Kabupaten Gorontalo Utara.

${ }^{10}$ Masita Naue, Kepala Madrasah Aliyah Anggrek, Wawancara, 24 Agustus 2016.
} 
untuk bekerja keras dalam memberdayakan seluruh potensi sumber daya madrasah menjadi jaminan keberhasilan sebuah madrasah.

3) Supervisi pendidikan adalah suatu perbuatan yang telah diprogramkan secara resmi oleh MA Anggrek. Jadi bukan perbuatan yang dilakukan tanpa perencanaan terlebih dahulu, tetapi direncanakan secara matang sebelumnya oleh kepala madrasah.

4) Pentingnya dilakukan supervisi selama ini adalah untuk mengetahui kemampuan guru melaksanakan pembelajaran, secara berkala.

5) Kepala madrasah sebagai supervisor dimaksudkan untuk meningkatkan pengawasan dan pengendalian terhadap guru-guru dan personel lain untuk meningkatkan kinerja mereka.

Supervisi sesungguhnya telah dilaksanakan oleh kepala madrasah yang berperan sebagai supervisor, tetapi dalam sistem organisasi pendidikan modern diperlukan supervisor khusus yang independen dan dapat meningkatkan objektivitas pembinaan dan pelaksanaan tugasnya.

Budaya kerja berbeda antara guru satu dengan yang lainnya, hal itu dikarenakan landasan dan sikap perilaku yang dicerminkan oleh setiap guru di MA Anggrek berbeda. Budaya kerja yang terbentuk secara positif akan bermanfaat karena setiap guru di madrasah tersebut membutuhkan sumbang saran, pendapat bahkan kritik yang bersifat membangun dari ruang lingkup pekerjaannya demi kemajuan di lembaga pendidikan tersebut. Budaya kerja mencakup nilainilai yang harus tercermin dalam sikap dan perilaku setiap individu dalam organisasi yang meliputi integritas, profesionalisme, keteladanan, dan penghargaan kepada $S D M$, yang secara bersama-sama berpengaruh terhadap produktivitas pelayanan. Dinyatakan oleh kepala madrasah bahwa budaya kerja di madrasah ini ditumbuhkan dengan adanya suatu keyakinan dan komitmen kuat merefleksikan nilai-nilai tertentu, misalnya membiasakan kerja berkualitas, sesuai standar, atau sesuai kaidah pembelajaran, efektif atau produktif dan efisien. Tujuan fundamental budaya kerja adalah untuk membangun sumber daya manusia seutuhnya agar setiap orang sadar bahwa mereka berada dalam suatu hubungan komunikasi dengan guru secara efektif dan efisien serta menggembirakan. Budaya kerja berupaya mengubah komunikasi tradisional menjadi perilaku manajemen modern, sehingga tertanam kepercayaan dan semangat kerjasama yang tinggi serta disiplin. ${ }^{11}$

Melaksanakan budaya kerja mempunyai arti yang sangat mendalam, karena akan merubah sikap dan perilaku sumber daya manusia untuk mencapai produktivitas kerja yang lebih tinggi dalam menghadapi tantangan masa depan. Di samping itu masih banyak lagi manfaat yang muncul seperti kepuasan kerja meningkat, pergaulan yang lebih akrab, disiplin meningkat, pengawasan fungsional berkurang, pemborosan berkurang, tingkat absensi menurun, terus ingin belajar, ingin memberikan terbaik bagi lembaga pendidikan. Berdasarkan pandangan tersebut dapat dikemukakan bahwa realitas budaya kerja guru ditunjukkannya melalui perilaku dalam pembelajaran dan kehidupan guru sehingga memberikan manfaat budaya kerja untuk meningkatkan kualitas sumber

${ }^{11}$ Masita Naue, Kepala MA Anggrek, Wawancara, 5 Oktober 2016 
daya manusia, kualitas hasil kerja, kuantitas hasil kerja sehingga sesuai yang diharapkan.

Dari sajian data di atas dapat disimpulkan sebagai berikut:

1) Budaya kerja ditunjukkan oleh adanya perilaku kerja guru yang meliputi nilai-nilai berupa: kerja keras, ulet, disiplin, produktif dan tanggung jawab, kreatif, dinamis, konsekuen dan responsif. budaya sebagai komponen penting untuk menyediakan suatu kondisi agar kinerja guru tumbuh dengan baik.

2) Budaya kerja guru telah dilakukan melalui penerapan fungsi guru yang mengajar di madrasah dengan perilaku yang baik, dengan kata lain cara guru mengajar yang menimbulkan perilaku yang baik dan profesional.

3) Ada beberapa nilai-nilai yang mendasari kehidupan kerja para guru MA Anggrek di antaranya adalah nilai-nilai sosial, yang terdiri atas nilai kemanusiaan, keamanan, kenyamanan, persamaan, keselarasan, efisiensi, kepraktisan. Budaya kerja ditunjukkan yang didasarkan kepada nilai-nilai demokratik seperti mendahulukan kepentingan orang banyak, kepatuhan, aktualisasi diri.

4) Nilai-nilai profesional yang dimiliki oleh guru dalam pembelajaran dan kehidupan di madrasah telah memberikan peningkatan budaya kerja guru termasuk keahlian, wewenang memutuskan, penolakan kepentingan pribadi, pengakuan masyarakat, komitmen kerja, kewajiban sosial, pengaturan sendiri, dan perilaku disiplin.

5) Masih terdapat kesenjangan sosial antara guru sebagai pemicu terjadinya perilaku yang mengarah kepada budaya kerja yang tidak baik.

6) Untuk memperbaiki budaya kerja yang baik di MA Anggrek, membutuhkan waktu bertahun-tahun untuk merubahnya sehingga telah dilakukan pembenahan-pembenahan yang dimulai dari sikap dan tingkah laku kepala madrasah kemudian diikuti guru melalui kegiatan supervisi.

7) Kesediaan untuk memberi dan menerima kontribusi dari dan atau kepada guru lainnya sebagai mitra kerja dalam mencapai tujuan pembelajaran adalah sangat penting.

8) Budaya kerja di madrasah ini ditumbuhkan dengan adanya suatu keyakinan dan komitmen kuat merefleksikan nilai-nilai tertentu, misalnya membiasakan kerja berkualitas, sesuai standar, atau sesuai kaidah pembelajaran, efektif atau produktif dan efisien.

Dari hasil informan diatas penulis mengamati bahwa realitas budaya kerja guru yang ada di Madrasah Aliyah Anggrek, dilihat dari beberapa nilai yang mendasari perilaku kerja guru yaitu, kerja keras, ulet, disiplin, kreatif dan tanggung jawab. Realitas yang ada menggambarkan bahwa guru memiliki kondisi yang sama baik yang PNS maupun yang non PNS, ada beberapa guru yang sudah memiliki kesadaran untuk mengimplementasikan budaya kerja, tetapi sebagian guru masih ada yang dinilai kurang dalam melaksanakan budaya kerja dilihat dari beberapa nilai yang mendasari perilaku kerja guru yaitu disiplin, salah satunya masih ada guru sering datang terlambat, tidak masuk kerja tanpa izin, dan tidak tepat waktu dalam melaksanakan tugas. 


\section{b. Faktor-Faktor yang Mempengaruhi Peningkatan Budaya Kerja Guru di MA Anggrek}

1) Kulifikasi Pendidikan

Kualifikasi pendidikan selain menjadi tuntutan profesi juga merupakan tuntutan yuridis formal bagi tenaga pendidik. Tuntutan tersebut menjadi wajib dipenuhi dan dimiliki oleh setiap guru agar memiliki legalitas dan dapat menunjukkan kredibilitasnya sebagai agen pembelajaran, sehingga dapat melaksanakan tugas keprofesiannya secara profesional. kualifikasi pendidikan berhubungan erat dengan kinerja guru dalam mengemban peran sebagai agen pembelajaran (learning agent). Kualifikasi pendidikan guru merupakan persyaratan yang harus dipenuhi terkait dengan kemampuan yang dibutuhkan untuk melaksanakan tugas. Kualifikasi pendidikan dapat menunjukkan kredibilitas seseorang dalam melaksanakan pekerjaannya. Kualifikasi pendidikan guru dengan kata lain merefleksikan kemampuan yang dipersyaratkan bagi guru untuk melaksanakan tugas sebagai pendidik pada jenjang, jenis, dan satuan pendidikan atau mata pelajaran yang diambilnya. kompetensi sebagai kapasitas untuk melakukan sesuatu dihasilkan dari proses belajar (pendidikan). Selama proses belajar, stimulus akan bergabung dengan isi memori dan menyebabkan terjadinya perubahan kapasitas untuk melakukan sesuatu.

Dikemukakan oleh informan bahwa faktor pendidikan merupakan syarat yang penting untuk memegang jabatan tertentu. Karena pendidikan merupakan salah satu faktor untuk meningktkan kompetensi seseorang. Hal ini disebabkan tingkat pendidikan akan mencerminkan pengetahuan dan keterampilan sebagai prediktor sukses kerja seseorang untuk dapat melaksanakan suatu pekerjaan. ${ }^{12}$ Dari penjelasan di atas dapat dipahami bahwa pada prinsipnya peningkatan kualifikasi pendidikan dalam jabatan sangat memperhatikan tugas guru, berorietasi pada mutu dan menghargai pelatihan, prestasi akademik, dan pengalaman mengajar serta prestasi tertentu yang telah dimiliki guru tersebut.

Menurut Kepala Madrasah bahwa Pendidikan merupakan persyaratan tingkat pendidikan yang dibutuhkan dalam memegang jabatan dan biasanya berkaitan dengan tingkat intelektual, serta tingkat pengetahuan yang diperlukan. Pendidikan yang menjadi persyaratan minimal di dalam sebuah organisasi. ${ }^{13}$

2) Komitmen Kepala Madrasah

Salah satu faktor yang mempengaruhi kompetensi supervisor dalam pengawasan budaya kerja adalah komitmen kepala madrasah yang tinggi dalam melaksanakan tugas dan tanggungjawabnya sebagai supervisor karena kegagalan program supervisi di madrasah sebagian besar disebabkan oleh kurangnya komitmen dari puncak pimpinan.

Dalam pengamatan penulis menunjukkan bahwa kepala madrasah memiliki komitmen yang tinggi untuk meningkatkan prestasi kerja guru. Hal ini terbukti dari adanya kesediaan untuk melayani guru dengan penuh perhatian, kasih sayang, saling koordinasi dan konsultasi antara kepala madrasah dan guru yang mengakibatkan perilaku guru dalam mengajar menjadi lebih baik seperti

\footnotetext{
${ }^{12}$ Maya Rifka Abdullah, Wakil Kepala Bidang Kurikulum Madrsah Aliyah Anggrek, Wawancara, 5 Oktober 2016

${ }^{13}$ Masita Naue, Kepala MA Anggrek, Wawancara, 5 Oktober 2016
} 
keuletan, integritas, serta tanggungjawab guru dalam menyusun RPP dan perangkat pembelajaran serta melaksanakan pembelajaran di kelas.

Hal ini dibenarkan oleh informan dengan menyatakan bahwa komitmen kepala madrasah sudah baik yang direalisasikan dalam berbagai bentuk seperti: menyediakan waktu untuk bekerja dan melayani guru dengan baik, koordinasi dan konsultasi antara kepala madrasah dan guru untuk memikirkan bersama upaya meningkatkan motivasi dan prestasi kerja, menjalin komunikasi dan koordinasi untuk membahas konten materi mata pelajaran, sikap kebersamaan dan keterbukaan dalam membina kepribadian. ${ }^{14}$

Pendapat tersebut mengisyaratkan bahwa komitmen kepala madrasah yang tinggi dalam bekerja melalui arahan kerja telah menjadikan pada diri setiap guru tertanam suatu kebersamaan yang kuat dalam menghadapi suatu permasalahan madrasah, keterbukaan yang tinggi dalam berbagai hal untuk menanamkan saling percaya satu sama lain.

Hal ini dibenarkan oleh informan lainnya bahwa komitmen yang tinggi yang ditunjukkan oleh kepala madrasah dalam melaksanakan tugasnya sebagai supervisor sangat berpengaruh terhadap upaya membangun persepsi yang sama, melangkah secara harmonis dalam melakukan supervisi. Kepala madrasah telah menunjukkan tanggungjawabnya meningkatkan kompetensi sebagai supervisor. ${ }^{15}$

Kondisi ini terjadi karena kepala madrasah sudah memiliki pemahaman yang cukup baik tentang kegiatan supervisi pembelajaran. Hal ini dapat dilihat dari pendapat yang dikemukakan informan bahwa supervisi pembelajaran yang dilakukan oleh kepala madrasah telah mampu meningkatkan kemampuan dan keterampilan guru dalam melaksanakan tugas pokoknya, yaitu mengelola proses pembelajaran dengan segala aspek pendukungnya, sehingga berjalan dengan baik, agar tujuan pembelajaran khususnya dan tujuan pendidikan umumnya tercapai. ${ }^{16}$

Terkait dengan pelaksanaaan supervisi pembelajaran di madrasah informan menjelaskan bahwa supervisor bertugas melakukan pemeriksaan perangkat administrasi perangkat pembelajaran yang disiapkan oleh guru seperti: desain pembelajaran, sistem penilaian, daftar hadir, dan daftar nilai. Hal ini dilakukan setiap awal semester sebelum pelaksanaan pembelajaran dimulai sehingga guru tersebut tampak telah siap dengan rencana pembelajaran. ${ }^{17}$

Selanjutnya informan kembali menambahkan bahwa setelah proses pembelajaran berlangsung, kepala madrasah melakukan supervisi terhadap guru untuk menilai kesesuaian pelaksanaan proses pembelajaran dengan program yang telah disusun, kelebihan yang dimiliki oleh guru dalam pengelolaan kelas, serta aspek apakah yang memerlukan pembinaan kepala madrasah. Pada setiap akhir kegiatan supervisi, kepala madrasah memberikan pembinaan bimbingan terhadap aspek-aspek tertentu yang memerlukan perbaikan oleh guru. ${ }^{18}$

\footnotetext{
${ }^{14}$ Sri Wilin Malengga, Guru al-Qur'an Hadis MA Anggrek, Wawancara, 5 Oktober 2016.

${ }^{15}$ Maya Rifka Abdullah, Guru Akidah Akhlak MA Anggrek, Wawancara, 5 Oktober

${ }^{16}$ Yamin M. Raja, Guru Fikih MA Anggrek, Wawancara, 7 Oktober 2016.

${ }^{17}$ Masita Naue, Kepala MA Anggrek, Wawancara, 7 Oktober 2016.

${ }^{18}$ Masita Naue, Kepala MA Anggrek, Wawancara, 7 Oktober 2016.
} 2016. 
Berdasarkan pendapat informan tersebut, dapat direfleksi bahwa supervisi pembelajaran dilaksanakan mulai dari pemeriksaan kembali terhadap kesiapan perangkat pembelajaran yang telah diteliti oleh kepala madrasah, dan selanjutnya memberikan petunjuk dan pembinaan seperlunya sesuai dengan data temuan pada guru mata pelajaran tersebut.

3) Kemampuan Komunikasi

Sebagaimana dikemukakan sebelumnya bahwa yang menjadi acuan dalam penyusunan rencana program supervisi pembelajaran di madrasah, sebagai pengawas kepala madrasah senantiasa mengkomunikasikan dengan teman sejawatnya baik dalam persiapan, proses pelaksanaan sampai dengan sistem evaluasi yang dilakukan untuk mengukur keberhasilan kegiatan supervisi tersebut. Jadi adanya komunikasi dengan teman sejawat merupakan salah satu faktor yang mempengaruhi kompetensi supervisor dalam pengawasan budaya kerja guru di MA Anggrek.

Pendapat ini dikemukakan informan berikut ini bahwa dalam penyusunan rencana kegiatan supervisi, bagi guru yang belum sempat disupervisi sebagian besar adalah guru-guru senior termasuk guru yang telah berpengalaman. Guruguru tersebut juga digunakan sebagai mitra kerja pengawas madrasah dan sebagai tutor sebaya dalam kegiatan pembelajaran sehari-hari. Para guru setiap hari saling mendiskusikan permasalahan yang dihadapi baik dalam penyusunan perangkat pembelajaran maupun dalam proses penyajian materi di kelas sampai kepada sistem penilaian. ${ }^{19}$

Mengacu pada hasil wawancara tersebut bahwa keterampilan perencanaan supervisi pembelajaran pada dasarnya telah dilaksanakan dengan cukup baik sesuai prosedur yang ada, dengan mengidentifikasi terlebih dahulu seluruh kebutuhan atau permasalahan ataupun kesulitan apa yang dihadapi guru dalam pembelajaran di kelas, guna penyusunan rencana kegiatan apa yang dilaksanakan oleh pengawas untuk perbaikan pembelajaran yang baik melalui komunikasi dengan teman sejawat.

Selanjutnya dalam pelaksanaan supervisi pembelajaran oleh kepala madrasah, informan mengemukakan bahwa sesuai dengan pemahamannya bahwa supervisi itu harus membantu guru melihat dengan jelas tujuan pendidikan nasional; membantu, membimbing guru dalam menggunakan metode dan alat pelajaran; memenuhi kebutuhan belajar; menilai kemajuan peserta didik dan hasil pekerjaan guru itu sendiri; membantu guru baru di madrasah sehingga bergembira dengan tugas-tugas yang diperolehnya; membantu guru agar waktu dan tenaga tercurah sepenuhnya dalam pembinaan peserta didik di madrasahnya. ${ }^{20}$

Sebagaimana dikemukakan bahwa madrasah yang efektif umumnya memiliki komunikasi yang baik terutama antar warga madrasah, madrasah dengan masyarakat. Menurutnya bahwa komunikasi yang baik telah membentuk teamwork yang kuat, kompak dan cerdas, sehingga berbagai kegiatan madrasah dapat dilakukan secara merata oleh warga madrasah. Komunikasi yang dibangun di madrasah ini adalah komunikasi tertulis dan komunikasi lisan. Semua bentuk

\footnotetext{
${ }^{19}$ Masita Naue, Kepala MA Anggrek, Wawancara, 7 Oktober 2016.

${ }^{20}$ Novial Pinga, Guru Matematika MA Anggrek, Wawancara, 7 Oktober 2016.
} 
komunikasi melibatkan seluruh warga madrasah sesuai bidang tugas masingmasing. ${ }^{21}$

Pendapat tersebut secara jelas memberikan gambaran bahwa dalam pelaksanaan supervisi pembelajaran untuk menggalang partisipasi aktif guru tersebut dalam peningkatan proses pembelajaran, perlunya menjalin komunikasi yang baik dan efektif. Pendapat tersebut juga mengandung pernyataan bahwa telah terjadi komunikasi yang efektif antara pengawas dan guru dalam mencari solusi yang tepat atas permasalahan yang dihadapi guru di kelas. Dengan adanya supervisi pembelajaran sangat membantu guru dalam memperbaiki pembelajaran yang dilakukannya, karena proses lahirnya kesadaran tentang kesalahan yang dilakukan tersebut biasanya akan lebih terpatri dalam diri guru, jika dibandingkan dengan pembinaan dan bimbingan yang diberikan. Adanya kemampuan guru untuk menemukan secara mandiri kesalahan dan kekurangannya tersebut sekaligus menunjukan adanya perubahan dari segi pemahaman tentang bagaimana sebenarnya mengaplikasikan kemampuan sebagai guru yang profesional.

Pendapat tersebut mengisyaratkan bahwa tingkat pemahaman kepala madrasah terhadap kegiatan supervisi pembelajaran sudah cukup baik sehingga menjadi faktor yang mempengaruhi kompetensinya dalam pengawasan budaya kerja di madrasah. Supervisi dilakukan oleh kepala madrasah dengan memperhatikan komunikasi dalam hubungan konsultatif, kolegial, dilaksanakan secara demokratis; terpusat pada guru; didasarkan pada kebutuhan guru; umpan balik berdasarkan data hasil observasi; dan bersifat bantuan profesional. Dengan demikian kepala madrasah selaku supervisor menjalankan peranan yang cukup strategis dalam meningkatkan prestasi kerja guru, yang pada gilirannya untuk meningkatkan prestasi madrasah. Kualitas peranan supervisi pembelajaran akan dapat meningkatkan profesionalisme guru yang selanjutnya berdampak positif terhadap prestasi peserta didik. Supervisi pembelajaran yang dilakukan merupakan bantuan kepada guru tersebut melalui perencanaan yang sistematis, pengamatan yang cermat, dan umpan balik yang objek dan segera. Dengan cara itu guru dapat menggunakan balikan tersebut untuk memperbaiki kinerja.

4) Motivasi yang tinggi

Sebagaimana disebutkan sebelumnya bahwa motivasi merupakan salah satu komponen penting dalam meraih keberhasilan suatu proses kerja, karena memuat unsur pendorong bagi kepala madrasah untuk melakukan supervisi. Suatu dorongan dapat berasal dari dalam dirinya sendiri, yang berupa kesadaran diri untuk bekerja lebih baik atau memberikan yang terbaik bagi guru dengan berbagai macam alasan yang baik dan luhur.

Terkait dengan apa yang harus dilaksanakan oleh kepala madrasah sebagai supervisor, informan mengemukakan bahwa supervisor memiliki motivasi yang kuat dalam melakukan supervisi pembelajaran khususnya berkaitan dengan budaya kerja guru. Motivasi yang tinggi ini ditunjukkan oleh kepala madrasah dalam bekerja yakni memberikan yang terbaik bagi guru misalnya ketika

${ }^{21}$ Masita Naue, Kepala MA Anggrek, Wawancara, 7 Oktober 2016. 
melakukan perbaikan atau pengarahan dengan semangat dan menyampaikan katakata yang baik. ${ }^{22}$

Kepala madrasah mengakui dirinya selalu memberikan motivasi kepada guru karena sebagai atasan tidak sekedar mendorong sebisanya, akan tetapi mempergunakan strategi sehingga menghasilkan yang lebih baik bagi pelaksanaan tugas dan tanggungjawabnya sebagai supervisor. Selain itu ditegaskan pula oleh kepala madrasah bahwa guru tidak semuanya memiliki budaya kerja yang baik sehingga terkadang perlu dorongan untuk menjadikan guru memiliki budaya kerja yang lebih baik. $^{23}$

Selanjutnya informan mengemukakan bahwa kepala madrasah memberikan dorongan kepada guru pada saat melaksanakan supervisi dengan cara memberikan penguatan, bertanya, mengadakan variasi, menjelaskan sehingga guru lebih baik dalam mengajar mulai dari membuka dan menutup pelajaran, membimbing diskusi kelompok kecil, mengelola kelas, mengajar kelompok kecil dan perorangan. Motivasi kepala madrasah telah memberikan perubahan pada motivasi guru mengajar termasuk budaya kerja yang terlihat dari adanya ketekunan, keantusiasan, serta berperan secara aktif setiap kegiatan. ${ }^{24}$

Pendapat tersebut memberikan gambaran bahwa motivasi kepala madrasah tampak ketika memberikan dorongan kepada guru untuk memperbaiki keterampilan dasar mengajar guru, mengemban tugasnya sebagai pendidik, pengajar dan pelatih. Motivasi kepala madrasah juga terlihat dari semangatnya dalam ketika memberikan bimbingan melalui diskusi-diskusi dalam pertemuan guru sejenis di tingkat madrasah, sehingga pelaksanaan supervisi pembelajaran berjalan dengan baik. ${ }^{25}$

Berdasarkan pendapat informan tersebut, dapat diperoleh gambaran bahwa motivasi kepala madrasah telah mempengaruhi kompetensinya dalam melakukan supervisi yang berakibat pada antusias guru yang cukup baik terhadap pelaksanaan supervisi pembelajaran yang dilakukan kepala madrasah, karena guru tersebut didorong untuk mengetahui kelemahan-kelemahan yang dimilikinya dalam pelaksanaan pembelajaran. ${ }^{26}$

Motivasi kepala madrasah tersebut ditunjukan melalui sikap profesionalnya dalam melaksanakan tugas dan fungsinya sebagai supervisor. Motivasi kepala madrasah dalam kegiatan supervisi sangat membantu dan mendorong guru untuk meningkatkan kemampuan professional dan budaya kerjanya, karena supervisi yang dilaksanakan oleh kepala madrasah merupakan pembinaan profesional khususnya budaya kerja guru.

Uraian tersebut menunjukan bahwa kegiatan supervisi yang dilakukan kepala madrasah sangat membantu dan membimbing guru untuk meningkatkan kemampuan dan keterampilan mengajarnya secara profesional. Sehingga kepala madrasah sebagai pimpinan madrasah sekaligus sebagai supervisor menjadi motor

\footnotetext{
${ }^{22}$ Yamin M. Raja, Guru Fikih MA Anggrek, Wawancara, tanggal 12 Oktober 2016.

${ }^{23}$ Masita Naue, Kepala MA Anggrek, Wawancara, tanggal 12 Oktober 2016.

${ }^{24}$ Sumarni Otoluwa, Guru Akidah Akhlak MA Anggrek, Wawancara, 12 Oktober 2016.

${ }^{25}$ Zubaida Miolo, Wakil Kepala MA Anggrek, Wawancara, 12 Oktober 2016.

${ }^{26}$ Yamin M. Raja, Guru Fikih MA Anggrek, Wawancara, 12 Oktober 2016.
} 
penggerak yang mempengaruhi guru bekerja secara profesional menampilkan kinerja tinggi untuk mencapai standar mutu pembelajaran yang diharapkan.

Hal ini ditegaskan kembali oleh informan bahwa tujuan utama pelaksanaan supervisi pembelajaran adalah untuk mengembangkan kemampuan guru dalam pembelajaran, sehingga pelaksanaan kegiatan tersebut terutama di madrasah dapat memberdayakan guru dalam pelaksanaan pembelajaran di kelas, untuk mengembangkan manajemen kualitas pembelajaran juga mengikutsertakan guru dalam pelatihan jika ada peluang yang diberikan kepada madrasah. ${ }^{27}$

Dari uraian tersebut diperoleh gambaran bahwa motivasi kepala madrasah terhadap bidang tugasnya dengan adanya pelaksanaan supervisi pembelajaran oleh kepala madrasah, selalu responsif/tanggap terhadap berbagai aspirasi yang muncul bagi peningkatan mutu pembelajaran. Guru selalu membaca lingkungan dan menanggapinya secara cepat dan tepat, bahkan mampu mengantisipasi hal-hal yang mungkin bakal terjadi sehubungan dengan melaksanakan tugasnya di bidang pembelajaran.

Motivasi kepala madrasah sebagai salah satu faktor yang mempengaruhi kompetensinya sebagai supervisor sebab motivasi tersebut sangat dibutuhkan guru dalam meningkatkan kinerjanya dan budaya kerja guru. Walaupun guru tersebut selama ini dianggap mempunyai komitmen yang tinggi dalam pengembangan profesionalitas, namun di sisi lain diberikan pembinaan dengan motivasi yang tinggi.

Adanya motivasi yang tinggi dari guru dalam melaksanakan tugasnya di bidang pembelajaran, dipengaruhi adanya motivasi yang tinggi dari kepala madrasah dan sikap kepala madrasah yang selalu membangun jaringan komunikasi dalam menerapkan supervisi pembelajaran di madrasah.

\section{Penutup}

Kompetensi supervisor dalam pengawasan budaya kerja guru di MA Anggrek dapat dibuktikan oleh adanya kemampuan kepala madrasah dalam merencanakan dan melaksanakan serta mengevaluasi pelaksanaan supervisi yang dilakukan dengan mengedepankan nilai-nilai humanisme dalam kaitanya dengan peningkatan budaya kerja guru MA Anggrek sehingga guru tidak saja profesional dalam melaksanakan tugas dan tanggungjawabnya tetapi juga memiliki kompetensi sosial dan kepribadian yang sesuai dengan diharapkan.

Faktor-faktor yang mempengaruhi peningkatan budaya kerja guru terdiri atas:

a) Kualikasi Pendidikan, faktor pendidikan merupakan syarat yang penting untuk memegang jabatan tertentu. Karena pendidikan merupakan salah satu faktor untuk meningkatkan kompetensi seseorang. Hal ini disebabkan tingkat pendidikan akan mencerminkan pengetahuan dan keterampilan sebagai prediktor sukses kerja seseorang untuk dapat melaksanakan suatu pekerjaan

b) Komitmen kepala madrasah dalam melakukan tugas dan fungsi sebagai supervisor, menyediakan waktu untuk bekerja dan melayani guru dengan

\footnotetext{
${ }^{27}$ Masita Naue, Kepala MA Anggrek, Wawancara, 12 Oktober 2016.
} 
baik, koordinasi dan konsultasi antara kepala madrasah dan guru untuk memikirkan bersama upaya meningkatkan motivasi dan prestasi kerja.

c) Komunikasi yang terjalin antara kepala madrasah dengan guru yang baik, Komunikasi yang dibangun di madrasah ini adalah komunikasi tertulis dan komunikasi lisan. Semua bentuk komunikasi melibatkan seluruh warga madrasah sesuai bidang tugas masing-masing.

d) Motivasi yang tinggi dari guru dan kepala madrasah dalam pelaksanaan supervise di MA Anggrek. Kepala madrasah memberikan dorongan kepada guru pada saat melaksanakan supervisi dengan cara memberikan penguatan, bertanya, mengadakan variasi, menjelaskan sehingga guru lebih baik dalam mengajar

1) Efektifitas tugas dan fungsi kepala madrasah terhadap budaya kerja guru di Madrasah Aliyah Anggrek telah dirasakan oleh guru melalui peningkatan budaya kerjanya sehingga terjadi perubahan pada kemampuannya merencanakan kegiatan pembelajaran; melaksanakan kegiatan pembelajaran; menilai proses dan hasil pembelajaran; memanfaatkan hasil penilaian bagi peningkatan layanan pembelajaran; memberikan umpan balik secara tepat, teratur, dan terus menerus kepada peserta didik, perubahan dalam perilaku melayani peserta didik yang mengalami kesulitan belajar; menciptakan lingkungan belajar yang menyenangkan; mengembangkan dan memanfaatkan alat bantu dan media pembelajaran; memanfaatkan sumber-sumber belajar yang tersedia; mengembangkan interaksi pembelajaran yang tepat; dan melakukan penelitian praktis bagi perbaikan pembelajaran terutama dalam perilaku mengajar guru maupun perilaku guru dalam kehidupan sehari-hari yang menggambarkan kompetensi sosial dan kompetensi kepribadian yang sesuai dengan harapan.

\section{DAFTAR PUSTAKA}

Arikunto, Suharsimi, Prosedur Penelitian Suatu Pendekatan Praktik, Jakarta: Rineka Cipta, 2002.

Budimansyah, Dasim, Model Pembelajaran Berbasis Portofolio, Bandung: Genesindo, 2003.

Departemen Agama. Al-Qur'an dan Terjemahnya, Bandung: Diponegoro, 2004.

Departemen Pendidikan Nasional RI, Undang-undang Republik Indonesia Nomor 20 Tahun 2003 Tentang Sistem Pendidikan Nasional, Bandung: Citra Umbara; 2003.

Permendikbud Nomor 66 Tahun 2013 Tentang Standar Penilaian

Pidarta, Made, Pemikiran Tentang Supervisi Pendidikan, Jakarta: Bumi Aksara, 1992.

Rahman, John, Budaya Kerja Guru dalam Meningkatkan Kualitas Pembelajaran di Sekolah (Jurnal Pendidikan Normalita), Gorontalo: Program Pascasarjana, UNG, 2005. 
Sahertian, Piet, Konsep Dasar dan Teknik Supervisi Pendidikan, Jakarta: Rineka Cipta, 2000.

Sanjaya, Wina, Strategi Pembelajaran, Jakarta: Prenada Media Group, 2008.

Tuloli, Nani, Pengembangan Pendidikan, Sumber Daya Manusia, Budaya, Agama dan Ilmu Pengetahuan, Gorontalo: IKIP Negeri Gorontalo, 2001. 